\title{
III
}

\section{Population Trends: The Eighteenth Century and Earlier}

\author{
The proper study of mankind is man.'
}

In its early years angina pectoris was for the most part an affliction of middleaged and elderly men, almost exclusively a complaint of the affluent and a "British disease". ${ }^{2}$ It was first reported in 1768 and became prevalent by the 1770s, a time when the population of England was growing rapidly and its expectation of life lengthening. It is therefore pertinent to examine the contribution of these demographic changes together with their wellsprings, magnitude and precise timing in relation to the emergence of angina. Differences in the extent to which the sexes and various age and social groups were affected need to be ascertained and explained if possible. Finally, any demographic explanation for the early geographical localizing of angina must be sought in a comparison of eighteenth-century population changes in England with those occurring elsewhere.

Despite high death rates in infancy, childhood and early adult life, many people in earlier centuries did live to middle and even old age. This was the case as long ago as the Classical Era. As an example, some nineteen prominent ancient Greek writers and fifteen Roman historians whose years of birth and death are known with reasonable certainty lived to beyond the age of sixty (Table III.1). ${ }^{3}$ Longevity was not then the good fortune of the famous alone. W R Macdonell surveyed inscriptions on memorial monuments in ancient Rome and its empire in Hispania and Lusitania, the modern Spain and Portugal respectively, and in Africa, the Morocco, Algeria and Tunisia of today. He showed, inter alia, that the age at death of males and females as recorded on each epitaph was over sixty years in about 5 per cent of the Roman inscriptions, 20 per cent of the Iberian and 22 per cent of the African. The numbers cannot be considered typical of life expectancy in the Roman empire generally. There are discrepancies between the findings in the three areas. The inscriptions appear to refer exclusively to Roman citizens and personal slaves, and therefore they probably memorialize persons of means. The scant number of early ages at death that were recorded on the inscriptions suggest that children who died were rarely remembered in this way (Table III.2). ${ }^{4}$

The expectation of life in Roman times that Macdonell calculated is very low by

\footnotetext{
${ }^{1}$ Alexander Pope, An essay on man, Epistle II.2. 209.

${ }^{2}$ William L Proudfit, 'Origin of concept of ischaemic heart disease', Br Heart J, 1983, 50: 209-12, p.

${ }^{3}$ Michael Grant, 'Ancient writers bibliography', in idem, The founders of the western world: a history of Greece and Rome, New York, Charles Scribner and Sons, 1991, p. 303.

${ }^{4} \mathrm{~W}$ R Macdonell, 'On the expectation of life in ancient Rome and in the provinces of Hispania, Lusitania and Africa', Biometrika, 1913, 9: 366-80, pp. 378-9.
} 


\section{Population Trends}

Table III.1

Some classical era notables living to beyond age 60

\begin{tabular}{|c|c|c|c|}
\hline \multicolumn{2}{|c|}{ Greek Writers } & \multicolumn{2}{|c|}{ Roman Historians } \\
\hline Name & Age at death & Name & Age at death \\
\hline Aeschylus & 68 & Cassiodorus & 93 \\
\hline Anaxagoras & 72 & St Jerome & 72 \\
\hline Antisthenes & 85 & Livy & 76 \\
\hline Aristotle & 62 & Nepos & 75 \\
\hline Callimachus & $65 / 70$ & Tacitus & about 61 \\
\hline Demosthenes & 62 & Dio Cassius & 80 \\
\hline Dionysius I & 63 & Eusebius & 86 \\
\hline Empedocles & 60 & Plutarch & over 70 \\
\hline Epicurus & 71 & Polybius & about 62 \\
\hline Euclides & 70 & Theodoretus & 73 \\
\hline Euripides & $74 / 79$ & Cato the Elder & 85 \\
\hline Isocrates & 98 & Pollio & 72 \\
\hline Pindar & 80 & Varro & 89 \\
\hline Plato & 82 & Emperor Claudius & 64 \\
\hline Simonides & 88 & Posidonius & 85 \\
\hline Sophocles & 90 & & \\
\hline Theophrastus & $82 / 85$ & & \\
\hline Xenophon & 76 & & \\
\hline Zeno & 72 & & \\
\hline
\end{tabular}

Sources: M Grant, 'Ancient writers bibliography', in idem, The founders of the western world: a history of Greece and Rome, New York, Charles Scribner and Sons, 1991, p. 303; M Grant, History of Rome, New York, Charles Scribner and Sons, 1978, p. 508.

Table III.2

Some records of inscriptions of age at death on Roman empire monuments

\begin{tabular}{lrrr}
\hline Ages & Rome & Iberia & Africa \\
\hline $40-49$ & 292 & 124 & 635 \\
$50-59$ & 146 & 109 & 611 \\
$60-69$ & 144 & 106 & 633 \\
$70-79$ & 89 & 93 & 726 \\
All ages* & 4,469 & 1,005 & 6,061 \\
\hline
\end{tabular}

* Includes deaths under 40 and over 80 years.

Source: W R Macdonell, 'On the expectation of life in ancient Rome and in the provinces of Hispania, Lusitania and Africa', Biometrika, 1913, 9: 366-80, pp. 378-9. 


\section{Chapter III}

current standards, but, whatever their shortcomings, his data show that it was by no means uncommon for ordinary Romans to live until late middle and even old age. A full life span as now understood was not unknown in the Middle Ages and three succeeding centuries. Of the twenty-four kings and queens of England who reigned between the Norman Conquest and 1768 and who escaped violent death, accidentally or at the hands of wartime enemies, rebellious subjects or usurpers, no fewer than fourteen lived to beyond the age of sixty years. ${ }^{5}$ At the beginning of the eighteenth century, over a quarter of the population of England was aged forty-five years or more. ${ }^{6}$

From 1538 onwards, births and deaths were recorded in all English parish registers. This procedure was initiated shortly after the break with Rome and establishment of the Church of England. The imposition of uniformity in religious practice at that time ensured that the registers would be comprehensive, with the possible exception of some infants who died before baptism or whose births were concealed. The information contained in some 404 of the 530 possible parish registers in various parts of the country was used by E Anthony Wrigley and Roger Schofield of the Cambridge Group for the History of Population and Social Structure for calculation of English population data from 1541 to 1871. Techniques were developed for dealing with data that deviated markedly from the average, whether from parish to parish or within a single parish in any particular year. Wrigley and Schofield had some doubts about the reliability of the data compiled during periods of acute disturbance, such as the mid-seventeenth-century Civil War, but considered them fairly accurate otherwise. ${ }^{7}$ Although religious diversity became widespread and increasingly tolerated during the eighteenth century, almost all births and deaths were still being recorded in Church of England parish registers, especially when this became compulsory in $1696 .^{8} \mathrm{~A}$ technique of back projection was used to calculate the yearly population size from 1541 onwards using totals of births and deaths, population numbers at a succession of points in time, and making allowance for individuals moving from one parish to another. ${ }^{9}$ After 1801 data thus obtained could be checked against census results and, starting some thirty years later, against government registration of vital statistics. As evidence of the validity of their methods, the nineteenth-century numbers obtained by the Cambridge Group were found to be in fairly close agreement with the new official figures. ${ }^{10}$

The Group revised the initial 1981 analysis with a technique of family data reconstitution. As an example, any one individual's baptismal, marriage and burial records could be related and age at marriage and death deduced. With enough individuals, expectation of life at various ages and times could be calculated, together

\footnotetext{
${ }^{5}$ John Cannon and Ralph Griffiths, The Oxford illustrated history of the British monarchy, Oxford University Press, 1989.

${ }^{6} \mathrm{E}$ Anthony Wrigley et al., English population history from family reconstitution 1580-1837, Cambridge University Press, 1997, pp. 614-15.

${ }^{7} \mathrm{E}$ Anthony Wrigley and R S Schofield, The population history of England 1541-1871: a reconstruction, Cambridge, MA, Harvard University Press, 1981, p. 31.

${ }^{8}$ Ibid., p. 28.

${ }^{9}$ Ibid., p. 8.

${ }^{10}$ Ibid., p. 199.
} 


\section{Population Trends}

Table III.3

Total population of England in the eighteenth century

\begin{tabular}{lc}
\hline Year & Thousands \\
\hline 1701 & 5,211 \\
1731 & 5,414 \\
1751 & 5,922 \\
1771 & 6,623 \\
1791 & 7,846 \\
1801 & 8,671 \\
\hline
\end{tabular}

Source: E Anthony Wrigley et al., English population history from family reconstitution 1580-1837, Cambridge University Press, 1997, p. 614 (with permission).

with other vital statistics. The great extent of the material that this yielded necessitated confining the later study to twenty-six parishes that were considered collectively to be representative of England as a whole. The newer technique facilitated effective use of the additional information and, pertinent to the present study, it resulted in some revision of the figures for the total population in any year and at various ages. For the eighteenth century the newer annual tabulations were for the most part the higher by about 3 per cent."

The Cambridge Group estimated that during the eighteenth century the population of England rose by about two-thirds, from just under five and a quarter million in 1701 to over eight and a half million by 1801 (Table III.3). During the second quarter of the century there was a slight and transient fall in number coinciding with a series of epidemics, so that almost all of the increase took place after $1750 .{ }^{12}$ Immigrants to England came mainly from other parts of the British Isles with small numbers from the Continent. These, however, were largely balanced by emigrants, to North America in particular. The latter numbered over half a million during the course of the eighteenth century. ${ }^{13}$ The rise in population must therefore of necessity have resulted from natural increase, due in turn to a decline in the death rate, a rise in the birth rate, or a combination of the two.

Which of these causes predominated has a direct bearing on estimates of any demographic contribution to the initial emergence of angina pectoris in the $1760 \mathrm{~s}$ and 1770s. Any increase in numbers of middle-aged and elderly people alive in these decades could have resulted only from a decline in adult death rates beginning in mid-century. A mid-eighteenth-century start in either a rise in the birth rate or a fall in infant and childhood mortality could not have had any appreciable effect on the numbers of the middle-aged and elderly until the 1790s at earliest, well past the critical period when angina pectoris first became manifest and then increasingly prevalent.

\footnotetext{
${ }^{11}$ Wrigley et al., op. cit., note 6 above, p. 614.

${ }^{12}$ Ibid., p. 614.

${ }^{13}$ B R Mitchell, British historical statistics, Cambridge University Press, 1988, p. 76.
} 


\section{Chapter III}

Based on their earlier data, the Cambridge Group concluded that an increase in the birth rate accounted for about two-thirds of the population increase during the last half of the eighteenth century. ${ }^{14}$ This presupposes that fertility could have been controlled and therefore limited at an earlier period. T McKeown has postulated that prior to the recent introduction of efficient means of contraception, fertility rates, unless adversely affected by severe female malnutrition, were unavoidably maximal and consequently there was, apart from some improvement in diet of the very poor, little room for any increase. ${ }^{15}$ However, there is evidence for limitations on fertility in earlier times, both voluntary and dictated by extraneous factors. Low illegitimacy rates in the eighteenth century indicate that abstinence was widely practised, as was coitus interruptus, ${ }^{16}$ a form of birth control known since Biblical times. ${ }^{17}$ Primitive barrier forms of contraception were not unknown and the wider birth spacing that follows prolonged breast feeding had been noted and possibly utilized as early as the seventeenth century. ${ }^{18}$ Lactation is now known to inhibit ovulation for several months and thereby reduce the likelihood of early post-partum conception, ${ }^{19}$ but reduced sexual activity while breast feeding and caring for an infant may also have contributed to deferment of a subsequent pregnancy. ${ }^{20}$

Dorothy George has suggested that a further, albeit one time contributory cause, was the decline in gin drinking after 1751, when duties on spirits were increased and their retailing controlled by Act of Parliament. ${ }^{21} \mathrm{~A}$ consequent reduction in alcoholinduced ill health among women of reproductive age could well have led to an increase in fertility. There was also an eighteenth-century betterment in nutritional status that benefited part of the population at least. It is largely attributable to an improvement in the availability, constancy, variety and quality of the food supply that followed changes in agricultural practice during the Georgian era, as detailed in Chapter IV. A good indicator of improving nutritional status is provided by contemporary records of the heights of individuals during years of growth and at maturity. Roderick Floud and his co-authors reported on the heights of military recruits born during a succession of five-year periods extending throughout the second half of the eighteenth century (Table III.4). Comparison of mid- and endcentury cohorts shows an average height increase at recruitment of 3.36 inches at age eighteen, 3.74 at nineteen, and 1.44 inches in men of twenty-four to twenty-nine years. The lower average heights of recruits in the earlier cohorts suggests suboptimal nutrition; the greater heights in the latest one is evidence of improvement. The increase in heights of men in the eighteen- and nineteen-year age groups over the course of half a century was greater than that of the older recruits. This suggests

\footnotetext{
${ }^{14}$ Wrigley and Schofield, op. cit., note 7 above, p. 245.

${ }^{15}$ T McKeown, The modern rise of population, London, Edward Arnold, 1976, p. 23. p. 29.

${ }^{16}$ Gigi Santow, 'Coitus interruptus and the control of natural fertility', Popul Stud, 1995, 49: 19-43,

${ }^{17}$ Genesis 38: 9.

${ }^{18}$ Santow, op. cit., note 16 above, p. 27.

${ }^{19}$ Iris Y Wang and Ian S Fraser, 'Reproductive function and contraception in the postpartum period', Obstet Gynecol Surv., 1994, 49: 56-63, 58-9.

${ }^{20}$ Santow, op. cit., note 16 above, p. 25.

${ }^{21}$ Dorothy M George, London life in the eighteenth century, New York, Harper and Row, 1965, pp. 516-17.
} 
Population Trends

Table III.4

Average height (in inches) of military recruits: quinquennial averages

\begin{tabular}{lccc}
\hline 1st quinquennial year & \multicolumn{3}{c}{ Age at recruitment } \\
\cline { 2 - 4 } & 18 & 19 & $24-29$ \\
\hline 1747 & 61.75 & 61.22 & 65.22 \\
1752 & 63.29 & 63.53 & 65.12 \\
1757 & 63.68 & 64.49 & 65.74 \\
1762 & 63.91 & 64.59 & 66.84 \\
1767 & 65.62 & 64.70 & 66.42 \\
1772 & 64.42 & 66.59 & 66.37 \\
1777 & 64.16 & 65.78 & 66.30 \\
1782 & 65.16 & 65.53 & 65.97 \\
1787 & 63.44 & 65.52 & 66.11 \\
1792 & 64.11 & 64.67 & 65.84 \\
1797 & 65.11 & 64.96 & 66.66
\end{tabular}

Source: Roderick Floud, A Gregory and $\mathrm{K}$ Wachter, Height, health and history: nutritional status in the United Kingdom 1750-1980, Cambridge University Press, 1990, pp. 506, 508 (with permission).

that in the earliest cohorts attainment of maximal height was delayed; in the latest ones it was sooner and thus further evidence of better nutrition. ${ }^{22}$ Although there may have been a tendency for male family members to have priority at the table, it is unlikely that females failed to derive any benefit from the improving food supply. Deficiency states are associated with late menarche, early menopause and with diminished vigour and fertility, all of which can be corrected by better nutrition. ${ }^{23}$

The Cambridge Group associated an increase in female fertility with a fall in the age of marriage that they had documented. The change was quite modest during the period here under review, the Group's estimates of the mean age of females at first marriage being twenty-six years in the first decade of the eighteenth century and about a year and a half earlier during its third quarter. ${ }^{24}$ However, because of the spread of the usually numerous births over many years, the youngest children would have been born during late years of female reproductive life and a time of fast declining fertility. A one year head start could have affected fertility favourably and appreciably by the end of, say, a twenty-year period of childbearing when the wife would have reached her forties, a time of rapidly diminishing likelihood of conception. This, for example, could have made the difference between having eleven rather than ten children. After a twenty-year interval, any initial increase in fertility would have raised both the numbers and the proportion of the population at ages

\footnotetext{
${ }^{22}$ Roderick Floud, A Gregory and $\mathrm{K}$ Wachter, Height, health and history: nutritional status in the United Kingdom 1750-1980, Cambridge University Press, 1990, pp. 506, 508.

${ }^{23}$ Susan Scott and C J Duncan, 'Nutrition, fertility and steady-state population dynamics in a preindustrial community in Penrith, northern England', J Biosoc Sci, 1999, 31: 505-23.

${ }^{24}$ Wrigley et al., op. cit., note 6 above, p. 134.
} 


\section{Chapter III}

Table III.5

Eighteenth-century infant and childhood mortality rate/1000/year

\begin{tabular}{lllll}
\hline Period & \multicolumn{5}{c}{ Age (in years) } \\
\cline { 2 - 5 } & $0-1$ & $1-4$ & $5-10$ & $0-15$ \\
\hline $1700-1724$ & 195.1 & 107.9 & 27.0 & 333.8 \\
$1725-1749$ & 196.3 & 121.0 & 28.4 & 348.1 \\
$1750-1774$ & 170.4 & 107.3 & 25.7 & 308.1 \\
$1775-1779$ & 166.0 & 107.7 & 22.7 & 297.9 \\
\hline
\end{tabular}

Source: E Anthony Wrigley et al., English population history from family reconstitution 1580-1837, Cambridge University Press, 1997, p. 262 (with permission).

of maximal reproductive activity, thereby initiating a cyclical course of rising birth rates.

The conclusions of the Cambridge Group have been disputed by proponents of decrease in mortality rates, especially in infancy and childhood, as the main cause of the rise in population numbers. Peter E Razzell has queried the completeness and reliability of the baptismal registration data on which the Cambridge Group's conclusions were based. He has also highlighted some difficulty in correcting for absence of birth entries of nonconformist families in the parish registers and also the problems arising as a result of people moving, and births, marriages and deaths being registered in different parishes as a result. ${ }^{25}$ Razzell has also drawn attention to the common eighteenth-century practice of memorializing a deceased child by giving his or her name to the next sibling of the same sex. The recorded marriage and death of the surviving brother or sister could therefore be linked erroneously with the birth of the deceased child. As a result, calculation of the surviving namesake's age at marriage and death would be over-estimated by the length of the interval between the births of the deceased and the next living siblings. ${ }^{26}$ Wrigley and his colleagues have included a detailed refutation of this critique in their 1997 publication. They point out, inter alia, that the same first name was not infrequently given to a younger sibling of a living child. Resulting errors in these circumstances would therefore have been random, and with adequate numbers they would have tended to cancel out. ${ }^{27}$

Data published by the Cambridge Group itself do indicate a modest fall in infant and child mortality between the first and last quarters of the eighteenth century (Table III.5).$^{28}$ Razzell has produced evidence to suggest that the mortality rates of adults also declined during the same period. A spinster marrying by licence when below the age of twenty-one was required to have the consent of her father, the mother if her father were dead, or a guardian if both parents were deceased. Registers

\footnotetext{
${ }^{25} \mathrm{P}$ E Razzell, 'The growth of population in eighteenth century England. A critical reappraisal', $J$ Econ Hist, 1993, 53: 743-71, p. 744.

${ }^{26}$ Ibid., p. 750.

${ }^{27}$ Wrigley et al., op. cit., note 6 above, p. 100.

${ }^{28}$ Ibid., p. 262.
} 


\section{Population Trends}

recording this form of marriage consequently noted whether one or both parents of the bride were alive or not on her wedding day. If alive, the parental age must have been thirty-five years at least. Between the periods 1677-1700 and 1751-1779 the percentage of brides with living fathers rose from 59 to 74; in the case of widowed mothers, there was almost no change, 20 and 21 per cent respectively, but the percentage of brides with both parents dead fell dramatically, from 21 to 4 per cent. The findings are convincing, but whether they are applicable to the whole country is problematic as the investigation was confined to the Canterbury area and the sources of similar studies that Razzell quoted were also localized. ${ }^{29}$

Several reasons for a decline in mortality rates have been suggested. Apart from a beneficial effect on fertility, Dorothy George has pointed out that there was a potential for improvements in maternal health following the decline in gin drinking. Alcohol related deaths among women could have become fewer, and with increasing sobriety there was scope for improvement in infant care and their survival to follow. ${ }^{30}$ Other possible reasons for falling mortality rates include the overall improved nutrition mentioned earlier and a rise in standards of cleanliness. For example, the newly introduced cotton replaced in part the use of wool and made the washing of clothes much easier. ${ }^{31}$ Razzell has also suggested that improved housing construction played a part, in particular with brick or stone replacing floors of bare earth. ${ }^{32}$ In addition, slates and tiles were being substituted for thatch in roofs. Both the roof and floor changes would have reduced contact with vermin. ${ }^{33}$ The late eighteenth century also saw some improvement in the physical environment of towns, especially in the better districts. Streets were being paved, piped water introduced, sewers constructed and exposure to waterborne infections consequently reduced. The differences between the protagonists of each of the two possible reasons for the eighteenthcentury population increase are mainly questions of emphasis. They have between them produced causes of and evidence for both increased fecundity and a decrease in mortality, whether in infancy, childhood or adult life.

The demographics of the capital are of special significance because it was in the metropolis that a disproportionately large number of the country's physicians then lived and where William Heberden practised for most of his professional life. During the Georgian era, death rates in London were greater than in the country as a whole. ${ }^{34}$ This reflected the appalling conditions under which most of the population of the burgeoning cities lived, ${ }^{35}$ the endemic fevers ${ }^{36}$ and periodic epidemics ${ }^{37}$ that ravaged the metropolis, and the probable lack of resistance to infection among the new arrivals from the relatively disease free countryside. ${ }^{38}$ Until 1775 , London

${ }^{29}$ Razzell, op. cit., note 25 above, p. 759.

${ }^{30}$ George, op. cit., note 21 above, p. 28.

${ }^{31}$ Ibid., p. 60.

${ }^{32}$ Razzell, op. cit., note 25 above, p. 766. p. 72 .

${ }^{33}$ Bill Breckon and Jeffrey Parker, Tracing the history of houses, Newbury, Countryside Books, 1991,

${ }^{34} \mathrm{~J}$ Landers, Death and the metropolis, Cambridge University Press, 1993, p. 175.

${ }^{35}$ Ibid., pp. 68-70.

${ }^{36}$ Ibid, p. 122.

${ }^{37}$ Ibid., p. 282.

${ }^{38}$ Ibid., p. 123. 


\section{Chapter III}

consistently suffered an excess of deaths over births, and it was only because of immigration from rural areas and the smaller towns that its population rose in number. ${ }^{39}$ In the early years of the eighteenth century, many Londoners did live to be elderly, but during the forty years leading to the time when angina pectoris was first reported, their numbers actually declined slightly. From December 1728 onwards, the London Bills of Mortality tabulated the number of deaths at various ages in ten-year groupings. My own perusal of the Bills for the first of these groupings, i.e. the decade ending in December 1738, showed that during this period 33,935 persons were aged sixty years or over at death. During the ten-year period that ended in December 1770 and encompassed the time when angina pectoris was first being described, the number of Londoners who were sixty or more at death had fallen marginally to 33,573 .

The eighteenth-century population trends in England as a whole diverged from those of the metropolis. In contrast to London, the overall number of individuals in the entire country who were aged sixty and over increased between the same two decades (1728-38 and 1760-70) by about one-fifth, from about 518,000 to 620,000 . In 1771 their percentage of the total population was 7.38 in contrast to 9.95 in 1701, the former being a smaller percentage of a far larger total number. ${ }^{40}$ The impact of rising fertility and fewer deaths in infancy and childhood apparently outweighed the more modest effects of declining mortality in adult life. The greater increase in the numbers of younger people had "diluted" the proportion of the older ones. Between the start of the century and 1771 the numbers of all English middle aged and elderly (defined somewhat arbitrarily as persons over forty-five), rose from 1,319,000 to $1,493,000$, a modest 13.2 per cent. This group encompassed almost all of the people vulnerable to coronary disease by reason of age..$^{41}$

In light of the characterization of angina as a "British disease", the demographic differences between England and elsewhere are modest. For example, mortality rates were greater in late-eighteenth-century France than in England (Table III.6), but the differences were not enough to have precluded many French men and women from living to middle life and beyond. ${ }^{42}$

There is evidence to indicate that the average life span of the British nobility increased considerably between the late seventeenth and late eighteenth centuries and in doing so overtook the expectation of life of the general population, the comparative changes being shown in Table III.7. T H Hollingsworth's data indicate that the percentage of the peerage who lived to fifty years during the last half of the eighteenth century was half as great again as the percentage of the general population who then only reached the age of forty-five..$^{43}$ Although there are some deficiencies, data concerning the nobility are close to comprehensive as there are records giving

\footnotetext{
${ }^{39}$ Wrigley et al., op. cit., note 6 above, p. 615.

${ }^{40}$ Ibid., pp. 614-15.

${ }^{41}$ Ibid., pp. 614-15.

${ }^{42}$ Wrigley et al., op. cit., note 6 above, p. 291.

${ }^{43} \mathrm{~T} \mathrm{H}$ Hollingsworth, The demography of the British peerage, Population Studies, 18: Supplement No. 2, London, Population Investigation Committee, London School of Economics, 1964, pp. 56-7; Wrigley et al., op. cit., note 6 above, pp. 614-15.
} 


\section{Population Trends}

Table III.6

Adult mortality/1000/year.

Sexes combined, England and France, ages 30-70

\begin{tabular}{lcc}
\hline Age & $\begin{array}{c}\text { England } \\
1750-1809\end{array}$ & $\begin{array}{c}\text { France } \\
1740-1789\end{array}$ \\
\hline $30-34$ & 54.1 & 62.7 \\
$35-39$ & 62.3 & 71.9 \\
$40-44$ & 68.1 & 86.2 \\
$45-49$ & 89.0 & 101.1 \\
$50-54$ & 101.1 & 119.1 \\
$55-59$ & 124.1 & 148.6 \\
$60-64$ & 172.1 & 203.4 \\
$65-69$ & 237.7 & 285.5 \\
\hline
\end{tabular}

Source: E Anthony Wrigley et al., English population history from family reconstitution 1580-1837, Cambridge University Press, 1997, p. 291 (with permission).

Table III.7

Expectation of life at birth: 1650-1774

Total population of England and British peerage

\begin{tabular}{|c|c|c|c|c|}
\hline \multirow{3}{*}{$\begin{array}{l}\text { Cohort year } \\
\text { of birth }\end{array}$} & \multicolumn{4}{|c|}{ Life expectancy (years) } \\
\hline & \multicolumn{2}{|c|}{ Total population* } & \multicolumn{2}{|c|}{ British peerage $\dagger$} \\
\hline & Male & Female & Male & Female \\
\hline $1650-74$ & 38.1 & 36.3 & 29.6 & 30.7 \\
\hline $1675-99$ & 35.4 & 35.4 & 32.9 & 34.2 \\
\hline $1700-24$ & 36.6 & 36.8 & 36.6 & 36.3 \\
\hline $1725-49$ & 35.8 & 37.4 & 38.6 & 36.7 \\
\hline $1750-74$ & 40.8 & 40.0 & 44.5 & 45.7 \\
\hline
\end{tabular}

* Source: E Anthony Wrigley et al., English population history from family reconstitution 1580-1837, Cambridge University Press, 1997, p. 308 (with permission).

† Source: T H Hollingsworth, The demography of the British peerage, Populations Studies, 18, Supplement No. 2, London, Population Investigation Committee, London School of Economics, 1964, pp. 56-7 (with permission).

the dates of birth and death of individual members of the peerage and their immediate families.

There are several possible reasons why members of the peerage ultimately had a greater expectation of life than the general population. A small part of the credit may be due to improvements in medical practice. The peerage had greater access to the very limited number of physicians practising in the mid-eighteenth century. In 1752 there were in England but 52 Fellows of the Royal College of Physicians of London, 3 candidates, 23 licentiates and a limited number of Edinburgh and foreign 


\section{Chapter III}

trained doctors, perhaps 100 in all. They became more numerous subsequently, but by 1783 , when the first comprehensive register was established, the total number of physicians for the whole of England was still only $363 .^{44}$ Their availability for serving the general population was limited, although some doctors did attend indigent patients in newly established dispensaries. ${ }^{45}$ To a very large extent the population as a whole used the services of the more numerous apothecaries or lay practitioners who were regarded by licensed physicians as quacks. Their diagnoses and treatments were in all probability even less substantiated than those of the Fellows of the Royal College.

The most notable eighteenth-century medical development was the introduction of measures to prevent smallpox, which had previously been the scourge of rich and poor alike. Its impact on the highest in the land during the seventeenth century can be gauged by its incidence in the Stuart royal family. Mary II, joint sovereign with William III, died of smallpox, as did two of the six children of Charles I, two of the five children of James II and the eldest son of Queen Anne. ${ }^{46}$ Lady Mary Wortley Montagu learnt of inoculation against smallpox while living in Constantinople, where her husband was the English ambassador to the Ottoman empire. She introduced the practice into England in 1721 and variolation (introduction of material from smallpox patients' pustules beneath the skin of the persons being immunized) became widespread among the well-to-do, especially after King George II and his family, including the royal princesses, consented to being inoculated. ${ }^{47}$ The side effects were far more severe than the vaccination using cowpox vaccine introduced by Jenner towards the end of the century. Risk of local abscesses was not inconsiderable and the live virus in the inoculum could on occasion induce a severe attack of smallpox. Nevertheless, variolation became increasingly popular, initially with the upper classes, among whom its effect on the incidence and mortality of smallpox became evident. A modified and safer technique of variolation came into widespread use by about the 1760 s, still well before its replacement by vaccination after $1798 .^{48}$

Since at least early Stuart times ague or marsh fever had been prevalent in England, possibly as a "new disease" that resulted from opening up of contacts with tropical Africa and America. ${ }^{49}$ Unlike so many fevers, it is clearly recognizable as malaria in the contemporary descriptions which detailed the periodicity of the febrile episodes. ${ }^{50}$ It was especially concentrated in marshy parts of south-east England, ${ }^{51}$ including lowlying areas of London. ${ }^{52}$ Recovery was usual, but the debilitating effects contributed p. 353.

${ }^{44}$ Joan Lane, 'The medical practitioners of provincial England in 1783', Med Hist, 1984, 28: 353-71,

${ }^{45}$ Ibid., p. 362.

${ }^{46}$ D R Hopkins, Princes and peasants: smallpox in history, University of Chicago Press, 1983, p. 40.

${ }^{47}$ P E Razzell, 'Population change in eighteenth-century England: a reinterpretation', Econ Hist Rev, 2nd series, 1965, 18: $312-32$, p. 318.

${ }^{48}$ Ibid., p. 318.

${ }^{49} \mathrm{M} \mathrm{J}$ Dobson, Contours of death and disease in early modern England, Cambridge University Press, 1997, pp. 328-9.

${ }^{\text {so }}$ Ibid., p. 295.

${ }^{51}$ Ibid., p. 321.

${ }^{52}$ Ibid., p. 315. 


\section{Population Trends}

indirectly to deaths from other causes. The introduction of cinchona or Peruvian bark in the late seventeenth century proved to be an effective remedy, this responsiveness further identifying the disease with malaria. ${ }^{53}$ It is probable that here too the aristocracy gained the most benefit, not only because proportionally fewer of them lived in the most swampy parts of the country, but also because they could the more readily afford the new treatment. Ultimately, drainage of the marshes was of general benefit in the affected areas.

The third change in medical practice that was of selective class advantage was the changing attitude of physicians to bleeding. Phlebotomy continued to be practised throughout the eighteenth century, but licensed physicians of the time adopted an increasingly conservative approach. The number of conditions for which their patients were bled tended to lessen and, if there were no immediate benefits, patients were the more frequently spared repeated venesections. ${ }^{54}$ There was a growing tendency to refrain from excessive bleeding if there were any untoward effects such as faintness, and to interrupt the procedure if the contralateral radial pulse became weak. The amount of blood removed was adapted increasingly to the body size and "strength" of the patient..$^{55}$ The privileged, who had the more ready access to physicians, gained the most from these advances. The general population had limited access to professional care, continued to be bled uncritically, often by friends or neighbours, and consequently suffered more frequent exposure to the attendant hazards.

Probably more important than medical advances, eighteenth-century improvement in hygiene was a cause of declining mortality among the privileged. Cleanliness became valued to an extent unknown previously. The lack of running water was not a problem for those fortunate enough to have an unlimited number of servants to fetch and carry. Soap was coming into wider use and among the upper classes it became customary to wash, bathe and have clothes laundered regularly. The newly available cotton garments could be cleaned more easily than the woollen ones that they replaced. ${ }^{56}$ With lessening civil strife in England, homes became less fortresslike with larger windows and better ventilation. The aristocracy were also among the first to benefit from the improvements in water supply and waste disposal of which mention has already been made. The improved hygiene was reflected primarily in a decline in mortality in infancy and early childhood. Among male children born to the English peerage, the probability of dying in the first five years of life fell from 338 per thousand in the $1650-74$ cohort to 191 in that of the 1750-74 quinquennium. The female equivalents were 323 and 187 respectively. ${ }^{57}$ The changes in living styles over the intervening hundred years were apparently proving beneficial.

In 1696 Gregory King placed the number of families whose head was either a nobleman or engaged in "middle class" occupations at a little over 80,000 (Table

\footnotetext{
${ }^{53} \mathrm{~L}$ S King, The medical world of the eighteenth century, University of Chicago Press, 1958, p. 129.

${ }^{54}$ Ibid., p. 319.

${ }^{55}$ George, op. cit., note 21 above, p. 60.

${ }^{56}$ Razzell, op. cit., note 25 above, p. 744.

${ }^{57}$ Hollingsworth, op. cit., note 43 above, pp. 54-5.
} 


\section{Chapter III}

Table III.8

English upper- and middle-class families 1688 (to nearest thousand)

Number of families

\begin{tabular}{lr}
\hline Nobility and gentry & 18,000 \\
Persons in office & 10,000 \\
Merchants and traders & 7,000 \\
Persons in law & 10,000 \\
Clergymen & 10,000 \\
Persons in sciences and liberal arts & 16,000 \\
Naval and military officers & 9,000 \\
TOTAL & 80,000
\end{tabular}

Source: Gregory King, Natural and political observations and conclusions upon the state and condition of England 1696, ed. G E Barnett, Baltimore, Johns Hopkins Press, 1936, p. 31.

Table III.9

English upper- and middle-class families mid-eighteenth century (to nearest thousand). Estimate by Joseph Massie 1759

\begin{tabular}{lc}
\hline & Number of families \\
\hline Nobility and gentry & 18,000 \\
Civil offices & 16,000 \\
Military and naval officers & 8,000 \\
Merchants & 13,000 \\
Manufacturers & 80,000 \\
Law & 12,000 \\
Eminent clergy & 2,000 \\
Lesser clergy & 9,000 \\
Arts and sciences & 18,000 \\
TOTAL & 176,000
\end{tabular}

Adapted from: P Mathias, The transformation of England: essays in the economic and social history of England in the eighteenth century, New York, Columbia University Press, 1979, pp. 186-7 (with permission).

III.8) ${ }^{58}$ During the eighteenth century there was a considerable increase in the size of the middle classes, comprised principally of the families of the more prosperous farmers, professional men, notably lawyers and clergymen, and persons engaged in manufacturing and commerce and finally their dependents. An estimate of the social structure of England in 1759-60, shown in Table III.9, indicates that during the intervening years there was more than a doubling to a total of 176,000 households, perhaps an increase from 500,000 to one million persons, or from about one-tenth

${ }^{58}$ Gregory King, Natural and political observations and conclusions upon the state and condition of England 1696, ed. George E Barnett, Baltimore, Johns Hopkins Press, 1936, p. 31. 


\section{Population Trends}

to about one-sixth of the total population of England. ${ }^{59}$ During the Georgian era these families, sometimes then designated as "the middling sort" considered the gap between themselves and the nobility to be much narrower than the gulf which separated them from the labouring classes. They therefore sought, to the extent that their means allowed, to emulate upper-class lifestyles. The families of the people in middle-class occupations would rarely have been as wealthy as members of the nobility, and incomes within any one occupation could vary widely. ${ }^{60}$ However, the "middling sort" as a class enjoyed freedom from overcrowding. Increasingly they were living away from their places of work and in more and well-ventilated, spacious, better constructed homes in ever more salubrious neighbourhoods. They were acquiring reasonable standards of cleanliness of person and clothes, and access to professional medical attention. In most instances they had diets that were adequate if not more than adequate. Whilst the large proportion of the middling sort living in London remained in some measure exposed to the adverse health consequences, their lifestyles and location would have conferred some degree of protection from the epidemic and endemic diseases that ravaged the metropolis. ${ }^{61}$ It is likely therefore that the growing life expectancy of the nobility was accompanied by a more or less corresponding increase among the middle classes. A rise in middle class expectation of life during the course of the Georgian era is attested by the findings of Southwood Smith who compared the course of insured lives of persons born between 1690 and 1790 , and calculated an extension of some 25 per cent during this time. His data were based on records of families whose heads could afford to lend money to the government through purchase of a tontine, that is an annuity shared by a number of subscribers and successively transferred after each death to the survivors in the group. ${ }^{62}$ Razzell, using the same method, found that during the Georgian era a considerable reduction in mortality was demonstrable among members of parliament and Scottish advocates. ${ }^{63}$ As noted earlier, he also documented an eighteenth-century rise in the proportion of parents who lived to see their under 21-year-old daughters marrying, an age of thirty-five at least. As his conclusions were based on information in records of marriage by licence, which was more costly than marriage by banns, the information he obtained probably related to families with means. ${ }^{64}$ The overall evidence presented suggests that the proportion of middle-class people who lived well into adult life and beyond probably exceeded that of the population as a whole, even though the extent cannot be quantified in the way that is possible for the entire population.

Twentieth-century epidemiological surveys have consistently established that, notwithstanding female vulnerability to the traditional risk factors, the frequency of

\footnotetext{
${ }^{59} \mathrm{P}$ Mathias, The transformation of England: essays in the economic and social history of England in the eighteenth century, New York, Columbia University Press, 1979, pp. 186-7.

${ }^{60} \mathrm{P}$ Langford, A polite and commercial people: England 1727-1783, Oxford University Press, 1992, pp. 61-3.

${ }^{61}$ Landers, op. cit., note 34 above, pp. 282, 347.

${ }^{62}$ Southwood Smith, 'On the evidence of the prolongation of life during the eighteenth century', Trans Nat Assoc Promotion Social Sci, 1857, p. 498.

${ }^{63}$ Razzell, op. cit., note 25 above, p. 765.

${ }^{64}$ Ibid., p. 759.
} 


\section{Chapter III}

coronary heart disease is much lower in women than in men until the age of about fifty-five. After fifty-five years, the female incidence approaches that of males. ${ }^{65}$ Currently, many more women than men now live beyond that age. As a consequence, the overall incidence among women is today less than among men but not greatly so. Conversely, in any society, the lower the proportion of women living beyond fifty-five and the smaller the ratio of women to men in older age groups, the lower would be the overall ratio of women to men vulnerable to coronary heart disease. Such was the situation in the eighteenth century because numerous pregnancies were the rule and maternal mortality rates high. Female expectation of life at birth was consequently no greater than that of males and the proportion of women living to fifty-five and beyond was about the same as that of men. ${ }^{66}$ These factors would have resulted in the proportion of Georgian era women among sufferers from coronary heart disease being lower than today. This was indeed the situation exemplified by Heberden's own series. Amongst nearly 100 of his patients with angina, there were only three females. ${ }^{67}$

In conclusion, there were 1,319,000 people in England aged forty-five or more at the start of the eighteenth century. By 1771 their numbers had increased to $1,493,000$, a modest 13 per cent, ${ }^{68}$ reflecting the impact on population growth of declining adult death rates from the early mid-eighteenth century onwards. The contribution made by a rising birth rate and a fall in infant and childhood mortality beginning in the mid-1700s would not have impacted on the number of over fortyfives until near the end of the century. The evidence presented earlier suggests that although the large numbers of the middle class who lived in London could not wholly escape its health hazards, the percentage of their over forty-fives probably rose by more than the national average. In addition, the actual numbers of middle class in that age bracket must have more than doubled because of their growing population base. The middle-class heads of family increased in number more than twofold between 1696 and $1759 .{ }^{69}$ However, the large-scale population growth that began in mid-century was due mainly to an increase in fertility and a decline in mortality in infancy and early childhood. ${ }^{70}$ These changes could not have impacted on growth in numbers of the middle aged until well after the 1770s when angina pectoris had already first been recognized and was apparently increasing in prevalence. The really substantial increase of the middle-class and middle-aged population came two or more decades later. Unfortunately these changes cannot be quantified with the degree of accuracy possible for the total population.

By the beginning of the eighteenth century only two possible instances of angina pectoris had been described in England during the whole of its recorded history.

\footnotetext{
${ }^{65}$ William B Kannel and Thomas J Thom, 'Statistical data of clinical importance, incidence, prevalence and mortality of cardiovascular disease', in J Willis Hurst and Robert C Schlant (eds), The heart, arteries and veins, 7th ed., New York, McGraw-Hill, 1990, pp. 627-8.

${ }^{66}$ Wrigley et al., op. cit., note 6 above, p. 308.

${ }^{67}$ William Heberden, Commentaries on the history and cure of diseases, London, T Payne, 1802, $\mathrm{p}$. 295.

${ }^{68}$ Wrigley et al., op. cit., note 6 above, p. 614-15.

${ }^{69} \mathrm{King}$, op. cit., note 58 above, p. 31 ; Mathias, op. cit., note 59 above, pp. 186-7.

${ }^{70}$ Wrigley and Schofield, op. cit., note 7 above, p. 245.
} 
The twenty or so people with the characteristic pain seen by Heberden alone between 1748 and 1768 were followed by a near fourfold rise in his numbers in half that time, and by case reports by close to a score of contemporary physicians. All the while it remained uniquely "a British disease" and confined almost exclusively to affluent middle-aged and elderly men. The eighteenth-century increase in their numbers cannot alone explain the initial emergence of angina pectoris virtually $e x$ nihilo and is insufficient to account in more than part for the extent of its subsequently rapid growing incidence. The demographic differences between Britain and elsewhere are also insufficient to explain by themselves the unique geographical distribution. The select group of patients with angina pectoris could have become susceptible to it only if other factors had emerged concurrently during the Georgian era and these must be sought. The demographics can contribute only some of the soil. It remains to find the seeds. 